\title{
A Bibliometric Analysis and Visualisation of Research Trends in Cobalt-Based Orthopaedic Implants
}

\author{
Sandeep Singh \\ ${ }^{\wedge}$ Department of Civil Engineering, Chandigarh University, Gharuan, Punjab, India 140413
}

Article History: Received: 11 January 2021; Accepted: 27 February 2021; Published online: 5 April 2021

\begin{abstract}
Cobalt is one of the widely used metal for orthopaedic implants. The bibliometric analysis had been conducted to understand the active authors, organizations, journals, and countries involved in the research domain of "Cobalt-based orthopaedic implants". All published articles related to "Cobalt-based orthopaedic implants" from "Scopus", were analyzed using the VOS viewer to develop analysis tables and visualization maps. This article had set the objective to consolidate the scientific literature regarding "Cobalt-based orthopaedic implants" and also to find out the trends related to the same. The most active journals in this research domain were the Journal of Orthopaedic Research. The most active country was the United States of America. The leading organization engaged in research regarding Cobalt-based orthopaedic implants was the Rush University Medical Center, United States of America. The most active authors were Hallab N.J.
\end{abstract}

Keywords: Orthopaedic-implants, Cobalt, Material engineering, Bibliometric analysis, VOS viewer,

\section{Introduction}

Orthopaedic implants are medical devices to replace a missing or damaged joint or bone. Various types of orthopaedic implants and practices are widely used in the medical world. Material engineering and surface engineering can play a significant role in the development of new types of orthopaedic implants; and in enhancing the performance of orthopaedic implants. Patient-specific orthopaedic implants are the trends of the day and can improve the performance and reduce the cost of implant (Haglin et al., 2016).

Cobalt is one of the widely used metal for orthopaedic implants. Poor performance, pain, and wastage of money due to orthopaedic implants are mainly due to corrosion and wear of implants. Corrosion of Cobalt-based orthopaedic implants leads to the rapid increase of metals in blood, serum and of a variety of tissues and organs (Michel et al., 1987). Similarly, various types of surface treatments and surface coatings can be conducted on orthopaedic implants to improve their competency to be used as a material for orthopaedic-implants. The carcinogenic potential of metal elements is another threat faced by users of Cobalt-based orthopaedic-implants. This can be reduced by using Sol-gel hybrid coatings in orthopaedic-implants based on Cobalt (Amato et al., 2005). In comparison with other metal implants, Cobalt-based orthopaedic implants are more toxic and produce inflammatory cytokines (Dalal et al., 2012). Cobalt-based toxicity can also cause hypersensitivity to human immune system human lymphocytes (Hallab et al., 2001). The orthopaedic longevity of Cobalt-based implants can be extended and orthopaedic infections of cobalt-based implants can be reduced by gentamicin-loaded silk fibroin coatings on 3D-printed porous Cobalt-based orthopaedic implants (Han et al., 2017). Dermatitis is another issue associated with cobalt-based orthopaedic implants (Rostoker et al., 1986). However, there are contradicting studies on cobalt toxicity, which had not found any pieces of evidence of toxicity among samples on Cobaltbased orthopaedic implants (Tolan, Sierra and Moyer, 2015).

This bibliometric analysis will be a useful platform for future researchers by realizing the top researchers, organizations, and countries involved in research regarding Cobalt-based Orthopaedic implants. This article is arranged into four sections. The first section is the introduction, followed by the discussion of the methodology by which the research was conducted. The third section deals with results and discussion. The fourth section deals with the conclusion. The following research objectives and research questions were framed for conducting bibliometric analysis systematically.

\subsection{Research Objectives}

a) To consolidate the literature regarding Cobalt-based orthopaedic implants

b) To find out the trends related to research in Cobalt-based orthopaedic implants

\subsection{Research Questions}

a) Who are the active researchers working on Cobalt-based orthopaedic implants?

b) Which are the main organizations and countries working on Cobalt-based orthopaedic implants?

c) Which are the main journals related to Cobalt-based orthopaedic implants?

\section{Research Methodology}

Scopus files had been used for this article. For the article selection, the Boolean used was TITLE-ABS (Cobalt orthopaedic implants) on 12/032021. All the tables in this paper were created by using Microsoft Excel and VOS Viewer. Grammarly was used for spelling and grammar checks. Mendeley was used for article review and 
citation. This paper had been inspired by bibliometric analysis in its presentation style, analysis, and methodology from the works (Farhat et al., 2013; Liao et al., 2016; Kolkailah et al., 2019; Rodríguez-Padial et al., 2019; Tran et al., 2019; Ullah et al., 2019; Shahid et al., 2020).

\section{Results and discussion}

\subsection{Results}

This first round of search produced an outcome of 490 documents, in 10 languages, out of which 466 documents were in English. The classification of document categories is shown in Figure 1. For improving the quality of the analysis, we had selected only the peer-reviewed articles and all other documents had not been considered. Thus after using filters "Article" and "English" the second round search produced an outcome of 351 English articles (both open access and others). This paper had used all English articles to conduct bibliometric analysis and visualization using VOS Viewer. The English research articles in this domain since 1969 had been shown in Figure 2.

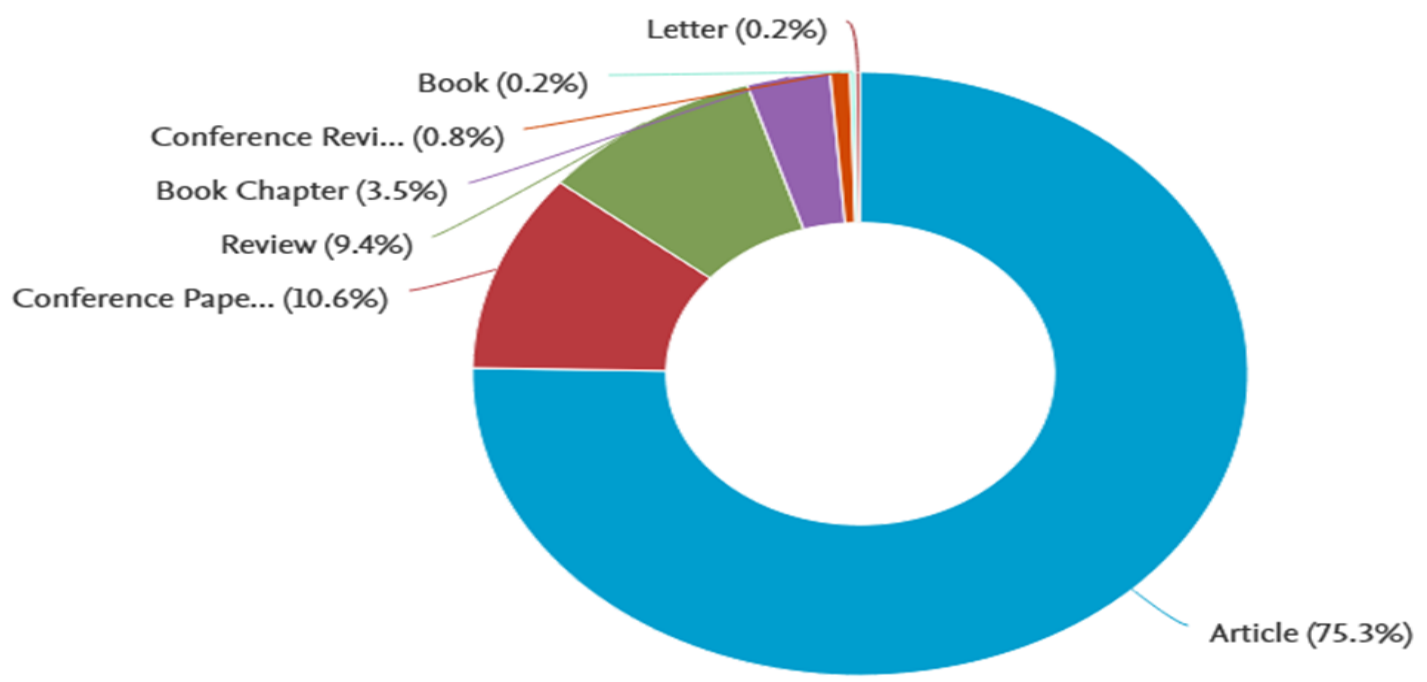

Figure 1: Classification of the documents on "Cobalt-based orthopaedic implants", Source: www.scopus.com

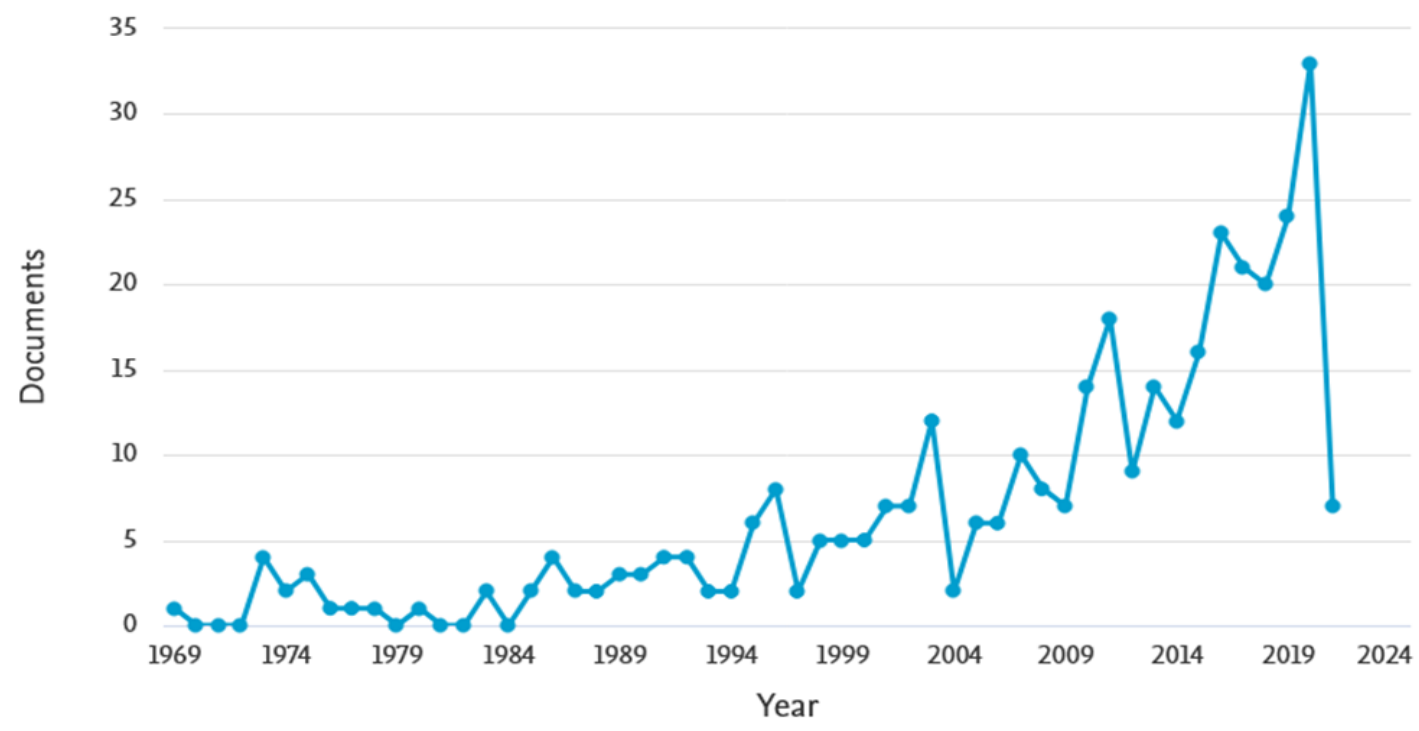

Figure 2: Period wise publication of articles, Source: WWW.scopus.com

Co-authorship analysis of top authors had been shown in figure 3. For a better presentation of the analysis, the parameters used were the minimum number of documents of an author as three and the minimum number of citations of authors as one. This combination plotted the map of 41 authors, in 18 clusters. The overlay visualization map of co-authorship analysis plotted in Figure 3, points out the major researchers with their strong co-authorship linkages and clusters involved. 


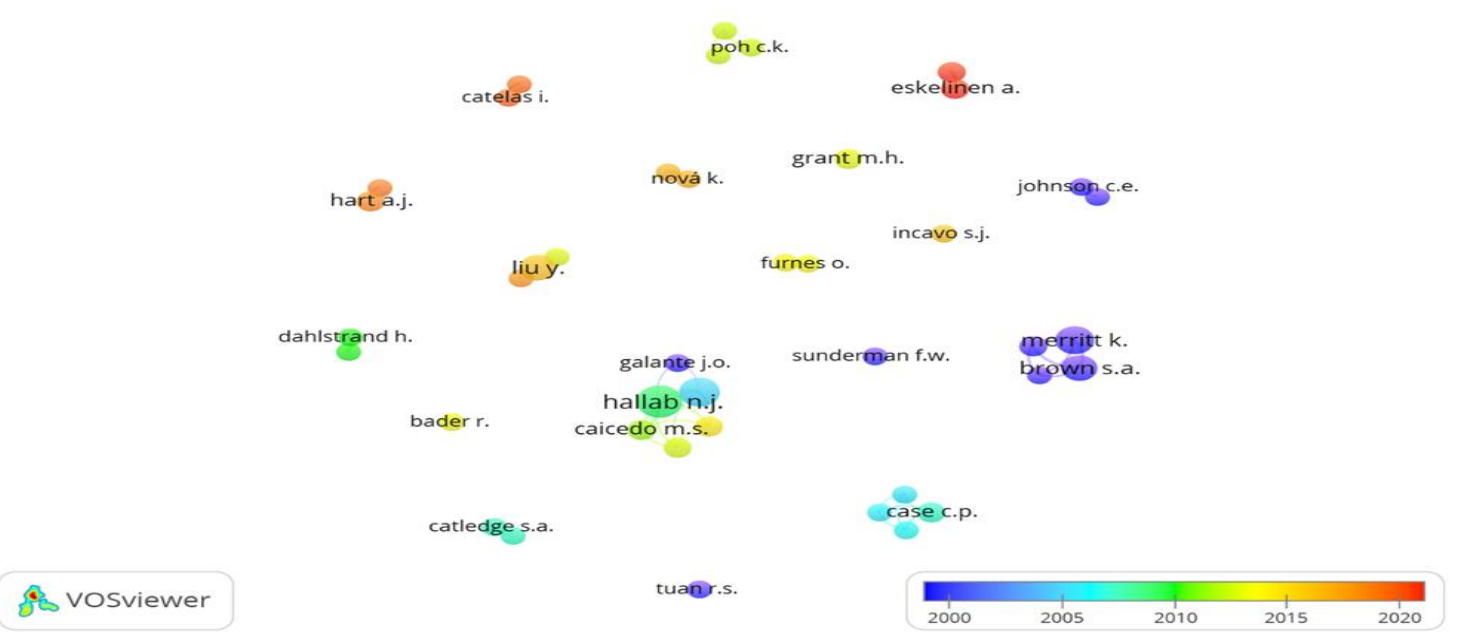

Figure 3: Co-authorship analysis on basis of authors

The citation analysis of top authors had been shown in table 1, along with co-authorship links. For the citation analysis, the parameters used were the minimum number of documents of an author as one and the minimum citations of an author as one.

Table 1: Highlights of most active authors

\begin{tabular}{|c|r|r|r|r|r|}
\hline Description & Authors & Documents & Citations & $\begin{array}{r}\text { Average } \\
\text { citations per } \\
\text { documents }\end{array}$ & $\begin{array}{r}\text { Link } \\
\text { strength }\end{array}$ \\
\hline $\begin{array}{l}\text { Authors with the } \\
\text { highest publication, } \\
\text { co-authorship links } \\
\text { and citations }\end{array}$ & Hallab N.J & 10 & & & \\
\end{tabular}

In Co-occurrence analysis, we had used all keyword analyses, by keeping the minimum number of occurrences of a keyword as 40. This combination plotted the map of 36 thresholds, in two clusters. The overlay visualization of co-occurrence analysis of keywords has been shown in Figure 4.

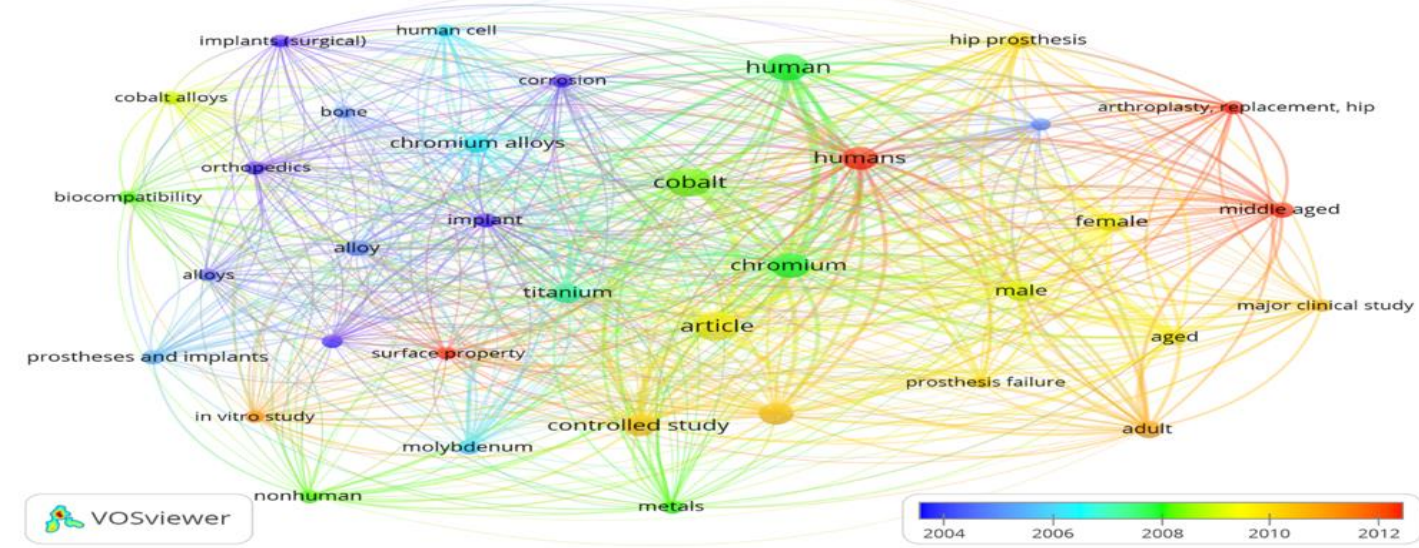

Figure 4: Co-occurrence analysis on basis of all keywords

The leading organizations engaged in research on "Cobalt-based orthopaedic implants" had been found out by the volume of publications and citation analysis, the parameters used are the minimum number of documents of an organization as one and the minimum number of citations of organizations as one. The leading organization in the research regarding "Cobalt-based orthopaedic implants", with the highest number of publications and citations, was the Rush University Medical Center, United States of America (Refer to table 2).

Table 2: Highlights of the most active organization

\begin{tabular}{|c|c|c|c|c|}
\hline Organizations & Country & $\mathrm{s}$ Document & Citatio & $\begin{array}{l}\text { Average } \\
\text { Citations } \\
\text { per } \\
\text { document }\end{array}$ \\
\hline Rush University Medical Center & $\begin{array}{c}\text { United States } \\
\text { of America }\end{array}$ & 16 & 1075 & 67.1 \\
\hline
\end{tabular}


Co-authorship analysis of the countries engaged in the research on "Cobalt orthopaedic implants" had been shown in Figure 5. The overlay visualization map of co-authorship analysis plotted in Figure 5, points out the main countries with their strong co-authorship linkages and clusters involved.

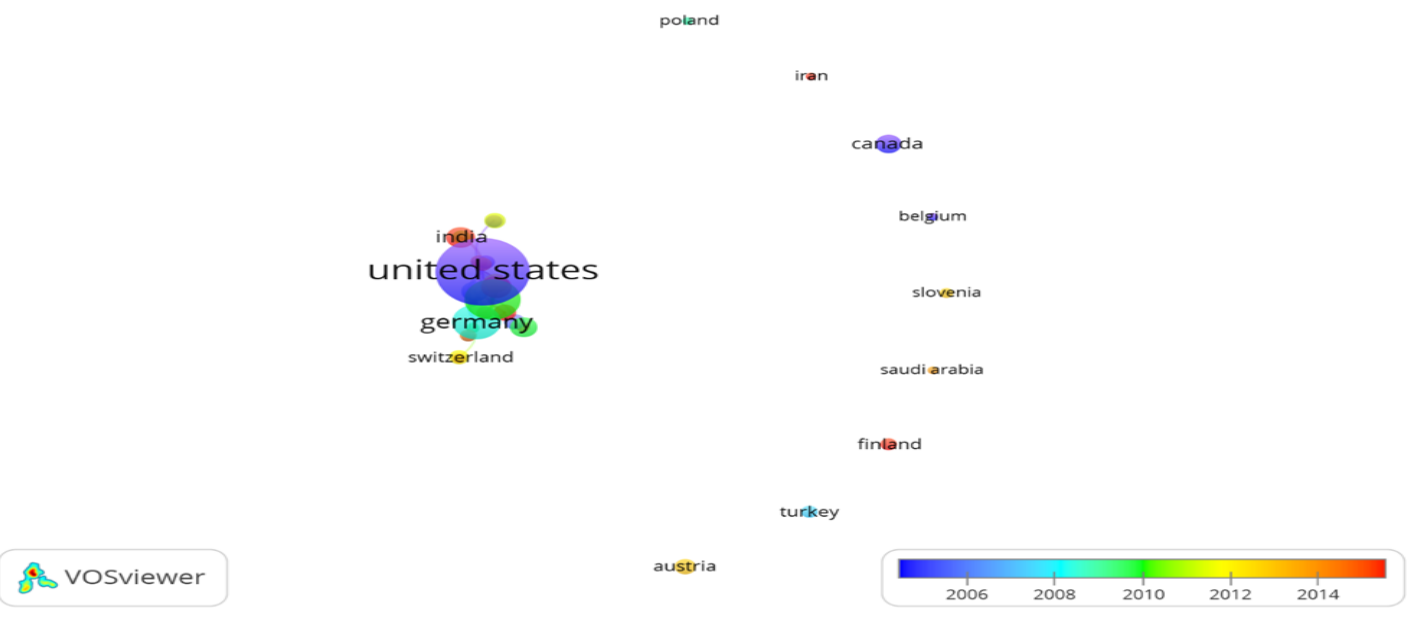

Figure 5: Co-authorship analysis on basis of countries

The citation analysis of top countries had been shown in table 3, along with co-authorship links. For the citation analysis, the parameters used were the minimum number of documents of a country as one and the minimum citations of the country as one.

Table 3: Highlights of Active Countries

\begin{tabular}{|c|c|c|c|c|}
\hline Description & Country Document & Citation & Link strength \\
\hline $\begin{array}{c}\text { The country with the } \\
\text { highest publication, links, } \\
\text { and citations }\end{array}$ & $\begin{array}{c}\text { United States of } \\
\text { America }\end{array}$ & 127 & 5665 & 26 \\
\hline
\end{tabular}

The most active countries in this research domain were the United States of America with the highest number of publications, co-authorship links, and citations.

Link analysis and citation analysis were used to identify the most active journal in this research domain. We have taken the parameters of the minimum number of documents of a journal as one and the minimum number of citations of a journal as one for the link analysis and citation analysis. Highlights of the most active and relevant journals related to "Titanium orthopaedic implants" are shown in table 4 . Table 4 shows the journal activity of this research domain through parameters of publication volume, citations, and co-authorship linkages.

Table 4: Analysis of journal activity

\begin{tabular}{|c|c|c|r|r|r|}
\hline Description & Journal details & Documents & Citations & $\begin{array}{c}\text { Average } \\
\text { citations } \\
\text { per } \\
\text { documents }\end{array}$ & Links \\
\hline $\begin{array}{l}\text { Journal with the } \\
\text { highest publications, } \\
\text { co-authorship links } \\
\text { and citations }\end{array}$ & $\begin{array}{c}\text { Journal of } \\
\text { Orthopaedic } \\
\text { Research }\end{array}$ & 48 & 1888 & 39.3 & \\
\hline
\end{tabular}

From the above discussion regarding the bibliometric patterns in the research regarding Cobalt-based orthopaedic implants, this research had observed a gradual increase in research interest regarding Cobalt-based orthopaedic implants from the starting of the millennium and the momentum is going on positively. This points out the relevance and potential of this research domain (Refer to Figure 2). The most active author in this research domain was Hallab N.J with the highest publication, co-authorship links, and citations (Refer to table 1). The overlay analysis of top countries researching orthopaedic implantations indicates that the United States of America was the leading country relating to the highest number of publications citations, co-authorship links (Refer to figure 5). The top journals of this research domain were identified as the Journal of Orthopaedic Research and, researchers can focus on top journals where they can identify the most relevant and highly cited articles regarding implants Cobalt-based orthopaedic implants.

\section{Conclusion}

The Cobalt-based orthopaedic implants was an interesting research domain and the most active journals related to this research domain were the Journal of Orthopaedic Research. The most active country was the United States of America. The leading organization engaged in research regarding Cobalt-based orthopaedic implants was the Rush University Medical Center, United States of America. The most active authors who had made valuable contributions related to orthopaedic implants were Hallab N.J. This research domain offers a new avenue for researchers and future research can be on Cobalt-based orthopaedic implants. 


\section{References}

1. Amato, L. E. et al. (2005) 'Electrochemical characterization of sol-gel hybrid coatings in cobalt-based alloys for orthopaedic implants', Materials Letters, 59(16), pp. 2026-2031. doi: 10.1016/j.matlet.2005.02.010.

2. Dalal, A. et al. (2012) 'Orthopedic implant cobalt-alloy particles produce greater toxicity and inflammatory cytokines than titanium alloy and zirconium alloy-based particles in vitro, in human osteoblasts, fibroblasts, and macrophages', Journal of Biomedical Materials Research - Part A, 100 A(8), pp. 2147-2158. doi: 10.1002/jbm.a.34122.

3. Farhat, T. et al. (2013) 'Research in congenital heart disease: A comparative bibliometric analysis between developing and developed countries', Pediatric Cardiology, 34(2), pp. 375-382. doi: 10.1007/s00246-012-0466-6.

4. Haglin, J. M. et al. (2016) 'Patient-Specific Orthopaedic Implants.', Orthopaedic surgery, 8(4), pp. 417424. doi: $10.1111 /$ os.12282.

5. Hallab, N. J. et al. (2001) 'Orthopaedic implant-related metal toxicity in terms of human lymphocyte reactivity to metal-protein complexes produced from cobalt-base and titanium-base implant alloy degradation', Molecular and Cellular Biochemistry, 222(1-2), pp. 127-136. doi: 10.1023/A:1017979710992.

6. Han, C. et al. (2017) 'Electrophoretic Deposition of Gentamicin-Loaded Silk Fibroin Coatings on 3DPrinted Porous Cobalt-Chromium-Molybdenum Bone Substitutes to Prevent Orthopedic Implant Infections', Biomacromolecules, 18(11), pp. 3776-3787. doi: 10.1021/acs.biomac.7b01091.

7. Kolkailah, A. A. et al. (2019) 'Bibliometric Analysis of the Top 100 Most Cited Articles in the First 50 Years of Heart Transplantation', American Journal of Cardiology, 123(1), pp. 175-186. doi: 10.1016/j.amjcard.2018.09.010.

8. Liao, J. et al. (2016) 'the most cited articles in coronary heart disease: A bibliometric analysis between 1970 and 2015', International Journal of Cardiology, 222, pp. 1049-1052. doi: 10.1016/j.ijcard.2016.08.002.

9. Michel, R. et al. (1987) 'Neutron activation analysis of human tissues, organs and body fluids to describe the interaction of orthopaedic implants made of cobalt-chromium alloy with the patients organisms', Journal of Radioanalytical and Nuclear Chemistry Articles, 113(1), pp. 83-95. doi: 10.1007/BF02036050.

10. Rodríguez-Padial, L. et al. (2019) 'Trends and Bibliometric Impact of Research Grants of the Spanish Society of Cardiology/Spanish Heart Foundation (2007-2012) [Evolución e impacto bibliométrico de las becas de la Sociedad Española de Cardiología/Fundación Española del Corazón en el periodo', Revista Espanola de Cardiologia, 72(12), pp. 1012-1019. doi: 10.1016/j.recesp.2018.08.013.

11. Rostoker, G. et al. (1986) 'Dermatitis due to orthopedic implants [DERMATOSES D'INTOLERANCE AUX METAUX DES MATERIAUX D'OSTEOSYNTHESE ET DES PROTHESES (NICKELCHROME-COBALT)]', Annales de Dermatologie ET de Venereologie, 113(11), pp. 1097-1108. Available at: https://www.scopus.com/inward/record.uri?eid=2-s2.00022844691\&partnerID=40\&md5=87ed793d5522a1086f2cbbc9705409a4.

12. Shahid, I. et al. (2020) 'Characteristics of highly cited articles in heart failure: A bibliometric analyses, Future Cardiology, 16(3), pp. 189-197. doi: 10.2217/fca-2019-0016.

13. Tolan, N. V, Sierra, R. J. and Moyer, T. P. (2015) 'Evidence against implant-derived cobalt toxicity: Case report and retrospective study of serum cobalt concentrations in an orthopaedic implant population', Clinical Biochemistry, 48(3), pp. 130-134. doi: 10.1016/j.clinbiochem.2014.10.012.

14. Tran, B. X. et al. (2019) 'The current research landscape of the application of artificial intelligence in managing cerebrovascular and heart diseases: A bibliometric and content analysis', International Journal of Environmental Research and Public Health, 16(15). doi: 10.3390/ijerph16152699.

15. Ullah, S. et al. (2019) 'Publication trends of Pakistan Heart Journal: A bibliometric study', Library Philosophy and Practice, 2019. 